\title{
Effects of Load Reductions on Phosphorus Concentrations in a Baltic Estuary-Long-Term Changes, Seasonal Variation, and Management Implications
}

\author{
Jakob Walve $^{1}$ (D) $\cdot$ Maria Sandberg ${ }^{1,2} \cdot$ Ragnar Elmgren $^{1} \cdot$ Christer Lännergren ${ }^{3,4} \cdot$ Ulf Larsson $^{1}$
}

Received: 29 October 2019 / Revised: 19 March 2020 / Accepted: 25 May 2020 / Published online: 10 June 2020

(C) The Author(s) 2020

\begin{abstract}
Nutrient concentrations in coastal waters are influenced not only by land runoff, point sources, and water exchange with the sea but are also modified by settlement to and release from sediments. This complicates evaluation of measures to reduce nutrient loads. We used a mass-balance box model to calculate long-term (1968-2015) and seasonal source contributions to phosphorus (P) concentrations and cycling in the stratified Stockholm inner archipelago (IA), Baltic Sea. A drastic reduction of sewage $\mathrm{P}$ loads in the early 1970s reduced sewage from the major to a minor P source. Further P load reductions in the 1990s cut the direct contribution from the sewage point sources to the annual mean surface water P concentration from $10 \mu \mathrm{g} \mathrm{l}^{-1}(25 \%)$ to $<4 \mu \mathrm{g} \mathrm{l}^{-1}$ (12\%). The largest contributions to the surface water P concentration are now (from 1996) inflowing seawater (37\%), freshwater (25\%), and P recycling from sediments below $20 \mathrm{~m}$ depth (26\%). Variations in freshwater flushing give higher P concentrations in dry years, when dilution of $\mathrm{P}$ inputs from sediments and sewage is small, while in wet years, these inputs are greatly diluted. Source-partitioned phosphate uptake shows that the spring bloom is fueled mainly by P of seawater and freshwater origin, while the contribution from sewage point sources is minor. Since sediment P release is mostly recycled P from the settled spring bloom, the $\mathrm{P}$ inputs from seawater and freshwater are now the major drivers of the IA P cycle. Recycling of P from sediments boosts surface water $\mathrm{P}$ concentrations in autumn and winter, affecting management target concentrations.
\end{abstract}

Keywords Phosphorus $\cdot$ Estuary $\cdot$ Load $\cdot$ Sewage $\cdot$ Sediment $\cdot$ WFD

\section{Introduction}

Excessive anthropogenic nutrient loading to coastal waters has often resulted in rampant eutrophication, with high phytoplankton biomass, turbid water, loss of benthic vegetation, and widespread deep-water hypoxia (Cloern 2001; Breitburg

Communicated by Margaret R. Mulholland

Electronic supplementary material The online version of this article (https://doi.org/10.1007/s12237-020-00769-2) contains supplementary material, which is available to authorized users.

Jakob Walve

jakob.walve@su.se

1 Department of Ecology, Environment and Plant Sciences, Stockholm University, SE-106 91 Stockholm, Sweden

2 Present address: Vikarbyn, Sweden

3 Stockholm Vatten AB, SE-106 36 Stockholm, Sweden

4 Present address: Hägersten, Sweden et al. 2018). Following nutrient load reductions, many areas have recovered, but due to complex interactions of physical, biogeochemical, and biological factors (Cloern 2001; Testa et al. 2017), responses vary, making it hard to predict the likely benefits of further reductions of nutrient loads. Physical factors, such as coastal morphology, water level fluctuations, and freshwater inputs govern flushing rates of surface and deep waters and thus nutrient exchanges with the open sea and the development of deep-water hypoxia. Microbial and chemical sediment processes, sensitive to hypoxia, temperature, and organic matter settling, regulate nutrient retention and recycling rates from sediments (Zhang et al. 2010; Walve et al. 2018).

In temperate areas, strong seasonal forcing adds to the complexity of nutrient cycling. Inputs of freshwater and nutrients, and thus estuary flushing rate, generally vary dramatically over the year. In winter, low light limits photosynthetic uptake of nutrients, which are largely exported at high flushing rates. Increasing light in spring usually stimulates a pronounced spring bloom, assimilating much of the accumulated and inflowing inorganic nutrients, which are partly retained by 
sedimentation. In summer, when flushing rates are usually lower, nutrients recycled from sediments often sustain much of the primary production (Staehr et al. 2017). In estuaries, the retention of nitrogen $(\mathrm{N})$ generally decreases as flushing rate increases (Nixon et al. 1996; Dettmann 2001). At high flushing rates, rapid export of nutrients may prevent negative eutrophication effects, while slowly flushed estuaries tend to be more influenced by recycled $\mathrm{N}$, and therefore more susceptible to eutrophication (Scavia and Liu 2009). In coastal waters, $\mathrm{N}$ is often the most important limiting nutrient for primary production, with $\mathrm{N}$-fixation insufficient to overcome the shortage of available N (Howarth and Marino 2006). Furthermore, binding of phosphorus $(\mathrm{P})$ tends to be ineffective in marine sediments (Blomqvist et al. 2004) and inflowing seawater often has a low $\mathrm{N}: \mathrm{P}$ ratio relative to phytoplankton needs (Howarth and Marino 2006), further enhancing N limitation. However, where the $\mathrm{N}$ loading with sewage or land runoff is high, $\mathrm{P}$ can control primary production.

The inner archipelago (IA) of Stockholm, Sweden's capital city, is an estuary in the NW Baltic Sea proper (Fig. 1), with a long history of eutrophication (Brattberg et al. 1991). In the 1970s, introduction of $\mathrm{P}$ precipitation in local sewage treatment plants (STPs) drastically lowered the P load, lowering concentrations of $\mathrm{P}$, chlorophyll (Brattberg et al. 1991; Boesch et al. 2006), and abundance of N-fixing and non-Nfixing nuisance cyanobacteria (Brattberg 1986). Chlorophyll and $\mathrm{P}$ concentrations of the IA continued to decrease during the 1980s (Lännergren and Stehn 2011; Boesch et al. 2006). With $\mathrm{N}$ loading still high, $\mathrm{P}$ was now clearly the limiting nutrient in the IA (Brattberg 1986; Boesch et al. 2006), resulting in large $\mathrm{N}$ export to the $\mathrm{N}$-limited middle and outer archipelago. After Sweden's 1995 accession to the European Union, the two largest STPs discharging to the IA added N removal in 1996, and further improved P removal. The IA remained largely P-limited, but the area of transition from $\mathrm{N}$ to $\mathrm{P}$ limitation moved inwards, towards the outer border of the IA (Lännergren and Stehn 2011).

It is debated to what extent the improvements seen after 1996 were due to the $\mathrm{N}$ or $\mathrm{P}$ load reductions, and whether additional removal of $\mathrm{N}$ or $\mathrm{P}$ is likely to give further improvement (Boesch et al. 2006; Schindler et al. 2008; Schindler and Vallentyne 2008). After the drastic Ptreatment effect on estuarine $\mathrm{P}$ concentrations in the 1970 s, the reasons for later $P$ concentration changes in the IA have been less clear. It has not been evaluated to what extent declining $\mathrm{P}$ concentrations in freshwater runoff and further lowered STP discharges of P caused the gradual decrease in P concentrations since the 1980s. The direct effect of improved P treatment in STPs from 1996 on P concentrations has also not been quantified. These analyses have been hampered by the poorly quantified, but evidently important, influence of seawater $\mathrm{P}$ inflow and $\mathrm{P}$ release from sediments (Boesch et al. 2006). A complicating factor is that sea and freshwater inflows not only contribute to $\mathrm{P}$ inputs but also affect the flushing of the IA, causing $\mathrm{P}$ concentrations to vary due to variable dilution of $\mathrm{P}$ inputs from STPs and sediments. Walve et al. (2018) concluded that sediment legacy P release was restricted to the first 10 20 years after the major P load reduction of the 1970s. Today, most of sediment $\mathrm{P}$ release is seasonal recycling of $P$ settled to the sediment during the preceding phytoplankton spring bloom, although release from inter-annual sediment $P$ storage can contribute, particularly in years of deepwater hypoxia (Walve et al. 2018).

Partitioning of the contributions of different $\mathrm{P}$ sources to the observed $\mathrm{P}$ concentrations can help explain the long-term changes and the yearly variations in $\mathrm{P}$ concentrations and associated ecological effects in the IA. From a management perspective, source partitioning can aid in setting appropriate concentration targets and selecting effective measures to further improve water quality. Of particular interest are the sources supplying P to the spring bloom, and thus to the subsequent large settling fluxes of organic matter that influence later sediment $\mathrm{P}$ release. Even though sediment $\mathrm{P}$ is not comparable with external sources, sediments can temporarily store $\mathrm{P}$ that, when released, can seasonally contribute substantially to phytoplankton growth. If the influence of seasonal sediment $P$ release on surface water $P$ concentrations can be estimated for assumed pristine conditions, the present $\mathrm{P}$ reference and target values according to the European Water Framework Directive (WFD 2000) assessment system (HVMFS 2013, 2018) can be improved. The currently used fresh- and seawater-mixing model may underestimate reference values by not accounting for the effect of seasonal recycling of $P$ from sediments. In addition, the contribution of $\mathrm{P}$ imported with the seawater inflow is of great interest since this source is hard to control and P concentrations in the Baltic Sea vary considerably (Fleming-Lehtinen et al. 2008). In this study, we address these issues using a mass-balance box model (Walve et al. 2018) to partition the contribution of different $P$ sources (STPs, freshwater, seawater, and release from deepwater $(>20 \mathrm{~m})$ sediments) to surface water $P$ concentrations and $\mathrm{P}$ cycling processes such as $\mathrm{P}$ uptake, settling, and export.

Specifically, we investigate: (1) how different P sources have contributed to the decreased $\mathrm{P}$ concentrations in the IA, in particular the decreased freshwater $\mathrm{P}$ concentration in the 1980s and the improved P removal by STPs from 1996; (2) how sea and freshwater inflows influence surface water P concentrations, by either diluting or promoting accumulation of $\mathrm{P}$ from high-concentration point sources and sediment $\mathrm{P}$ release; (3) the relative contribution to the spring bloom $\mathrm{P}$ uptake by different $\mathrm{P}$ sources and thus to the subsequent $\mathrm{P}$ release from sediments; (4) the influence of sediment $\mathrm{P}$ recycling on natural $\mathrm{P}$ concentrations and thus for reference values defined under the WFD; and (5) the seawater contribution to the $\mathrm{P}$ concentration and WFD status classification. 
Fig. 1 Maps showing the location of the Stockholm inner archipelago (IA) in the northwestern Baltic Proper. Lake Mälaren with drainage area is shown on the top left map and its outlet Norrström in Stockholm (LM) on the lower map. The local drainage area of the IA is indicated by the grey line in the lower map, which also shows the outer border of the IA. The central stations (A, $\mathrm{AV}, \mathrm{H}, \mathrm{L}$, and $\mathrm{K}$ ) were used to represent the IA. The main water exchange between the IA and middle archipelago is through Oxdjupet $(\mathrm{O})$. Data from Trälhavet (T) were used to represent inflowing seawater. Depths $(\mathrm{m})$ in maps are spline interpolated from nautical chart data (scale 1:25000, published 1984)
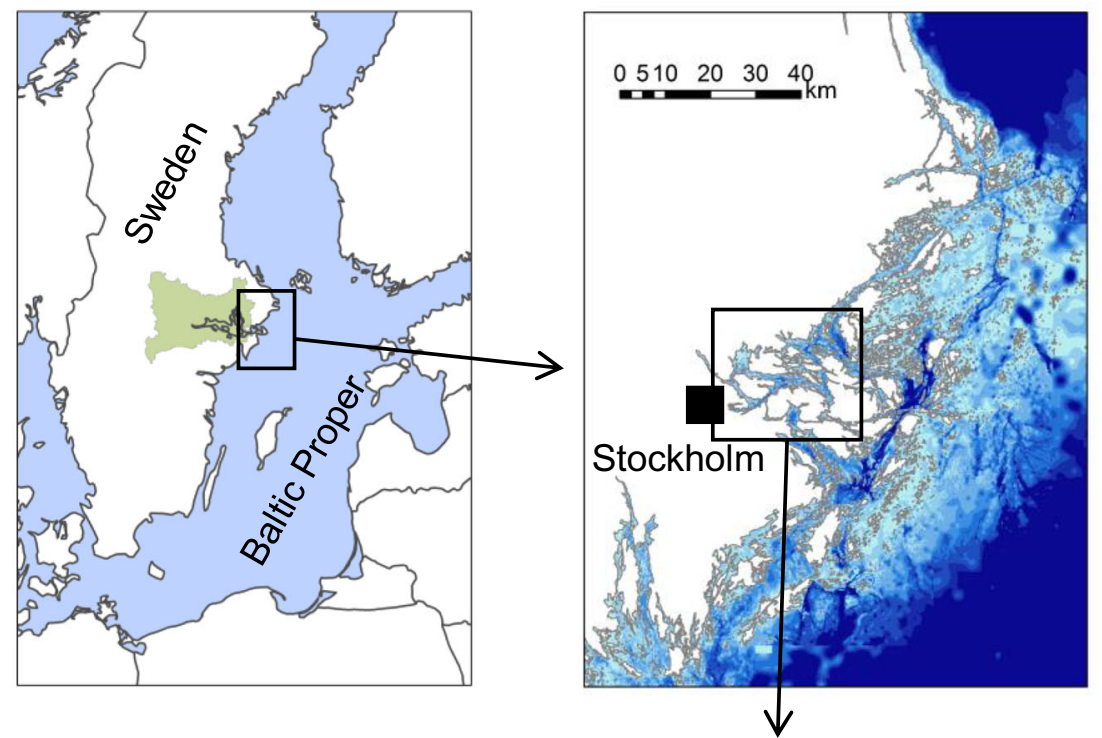

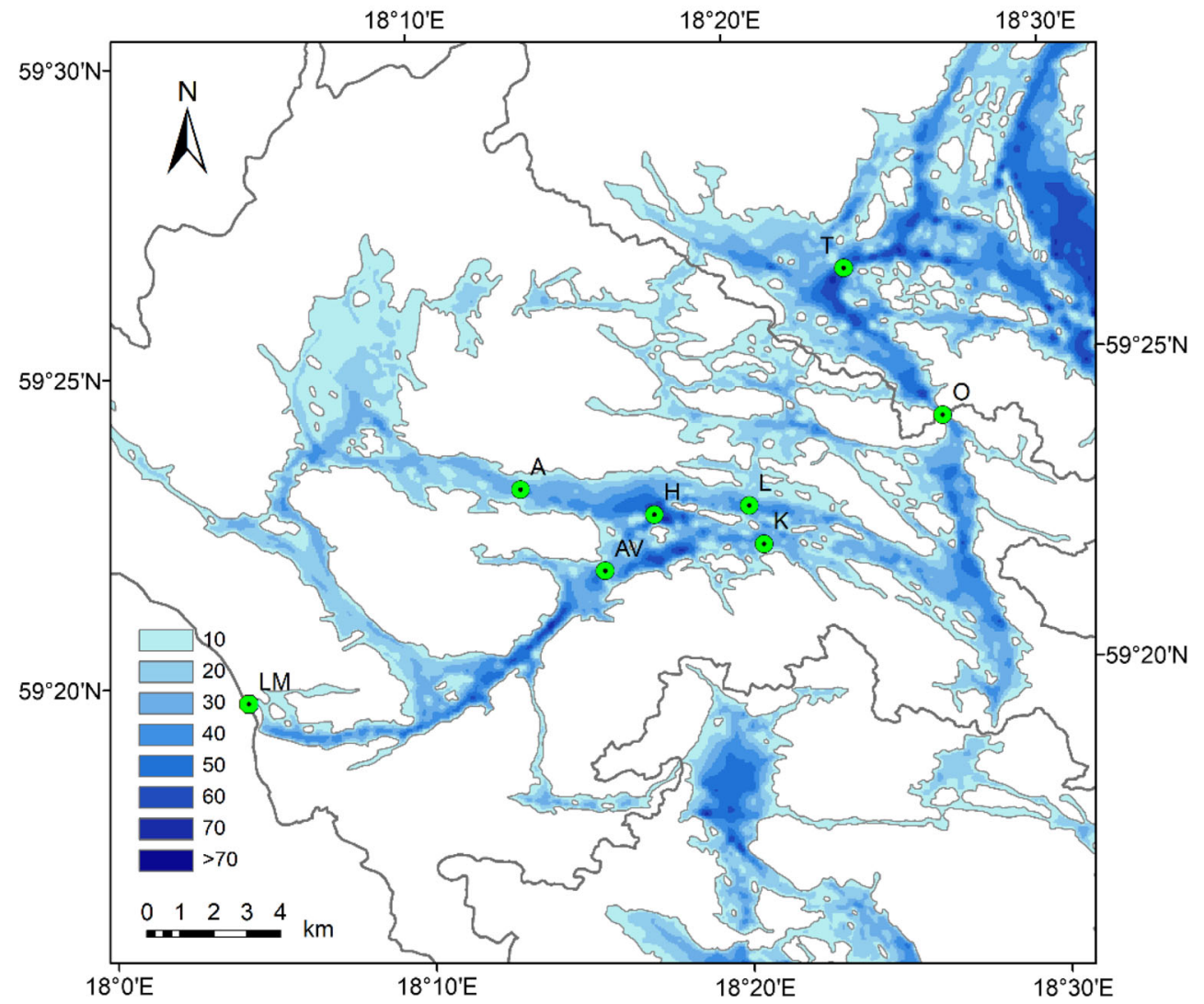

\section{Materials and Methods}

\section{Study Area}

The Stockholm archipelago comprises $\sim 24,000$ islands (Hedenstierna 1948). Lake Mälaren (drainage basin 22,000 $\mathrm{km}^{2}$ ) is its dominant freshwater source and empties to the relatively enclosed IA through central Stockholm (Fig. 1).
The IA has a small local drainage area of $323 \mathrm{~km}^{2}$, a water surface area of $103 \mathrm{~km}^{2}$, a maximum depth of $57 \mathrm{~m}$, and a mean depth of $14 \mathrm{~m}$ (SMHI 2003), with shallow areas mostly confined to relatively peripheral sub-basins. It connects to the middle archipelago through one major and three shallow minor straits. The major, $18 \mathrm{~m}$ deep Oxdjupet strait has the only significant deep seawater inflow and $\sim 84 \%$ of the surface water outflow (Engqvist and Andrejev 2003). Estuarine 
circulation, generated by the large freshwater inflow, mainly governs the water exchange, with wind and barotropic forcing less important, and tide negligible (Engqvist and Andrejev 2003).

\section{Water Circulation Model}

Data (1968-2015) sources and model set-up follow Walve et al. (2018), where the model is described in detail. It is a one-dimensional box model with estuarine water circulation, i.e., an inflow of seawater to the deep water and an outflowing less saline surface water. We here use the "mean model" version (Walve et al. 2018), a conventional, nonsteady-state approach with water flows constrained by salinity of outflowing surface water (as mean for the IA), by discharge of freshwater to the IA, and by changes in total salt amount in the IA. The model computes inflow of seawater to the deep water, upwelling, mixing, and outflow of surface water. We used the ExtendSim8 software (Imagine That Inc.), which is suitable for sequential computations and interpolations of large data sets, with a time step of 1 day and computation $\mathrm{d} t$ $=100$ day $^{-1}$.

\section{Phosphorus Data and Budget}

P budgets were made for total P (TP, persulfate-digested samples) and dissolved inorganic $\mathrm{P}$ (DIP, i.e., molybdate reactive $\mathrm{P}$, predominantly phosphate). $\mathrm{P}$ inputs to the IA come with freshwater (Lake Mälaren and local land runoff), with inflowing seawater and from STPs (Fig. 2). Seawater P import was calculated from the seawater inflow and the $P$ concentration at 20-30 m depth in Trälhavet, just outside the IA border (Fig. 1). Atmospheric P deposition on the IA is very small compared with other $\mathrm{P}$ sources, and therefore disregarded (Walve et al. 2018). The P export is a function of the surface water outflow and the volume-weighted $\mathrm{P}$ concentration in the surface layer.

In the default model, with all contributing sources, the $\mathrm{P}$ concentrations in all layers were continuously adjusted to fit interpolated observations, by additions or removal from the model. We used the summed adjustments as estimates of net internal losses from, or inputs to, the water column, for each water layer. To minimize influence of possible errors in the distribution of $\mathrm{P}$ uptake or $\mathrm{P}$ release among the three upper water layers of the water circulation model $(0-4,4-10$, and 10-20 m), we pooled model results into budgets for $0-20 \mathrm{~m}$ ("surface water") and 20-57 m ("deep water"). The P input needed to balance the deep-water $\mathrm{P}$ budget is interpreted as $\mathrm{P}$ release from deep-water sediments (Fig. 2). The net P loss from the surface layer is interpreted as net TP sedimentation (or net DIP uptake) from the surface layer. Due to initial analytical problems when a new monitoring laboratory was engaged affecting P data from the IA and Lake Mälaren in 2011 (Walve 2012), this year was excluded from the model analysis.

\section{Source Partitioning of P Concentrations and Losses}

To estimate the contribution of different $\mathrm{P}$ sources to the TP and DIP concentrations and to TP and DIP loss in the 0-20-m surface layer (S), the model was repeatedly run with normal water inflows, upwelling and mixing, for each $\mathrm{P}$ source

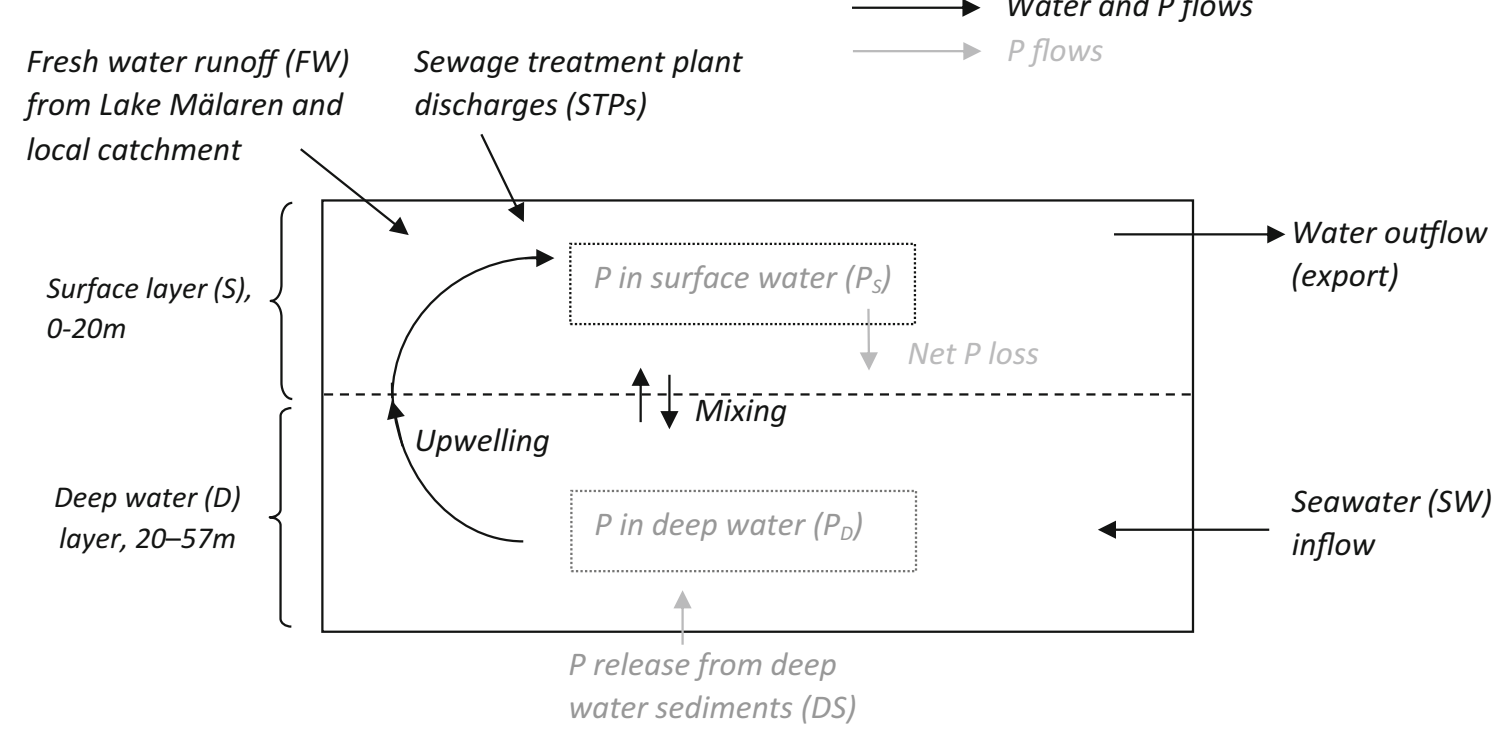

Fig. 2 Conceptual model diagram of the water and phosphorus $(\mathrm{P})$ flows in the Stockholm inner archipelago. The flux of $\mathrm{P}$ to the surface water is from freshwater (FW) runoff, sewage treatment plant discharges (STPs) and from upwelling and mixing of deep water containing P mainly from seawater (SW) inflow and recycled from sediments (DS). Net P release in the deep water and net $P$ loss in the surface water were calculated from the P budgets of the respective water layers (see "Methods") 
separately: STP discharges, Lake Mälaren discharge, local catchment runoff, seawater inflow, and $\mathrm{P}$ release from deepwater (> $20 \mathrm{~m}, \mathrm{D})$ sediments. For STPs and freshwater P sources, the P concentration in the IA 0-20 m layer (S) was calculated for each source from the mass balance

$\Delta P_{\mathrm{S}}=P_{\text {load }}+P_{\mathrm{Du}}-P_{\text {export }}-f \times P_{\mathrm{S}}$

where the $\Delta P_{\mathrm{S}}$ is the change in $P$ amount in the $0-20$-m surface layer (S), $P_{\text {load }}$ is new input to the surface layer from freshwater or STPs, $P_{\mathrm{Du}}$ is the flux of P from deep-water (D) upwelling and mixing, and $P_{\text {export }}$ is surface water outflow of $\mathrm{P}$ from the IA. The last term $f \times P_{\mathrm{S}}$ is the $P$ loss from the surface water by uptake or sedimentation, where $f$ is the daily loss fraction of the $\mathrm{P}$ amount in surface water, $P_{\mathrm{S}}$.

For seawater and deep-water sediment sources the mass balance is

$\Delta P_{\mathrm{S}}=P_{\mathrm{Du}}-P_{\text {export }}-f \times P_{\mathrm{S}}$

Here, the only $\mathrm{P}$ input $\left(P_{\mathrm{Du}}\right)$ is by deep-water upwelling and mixing of $\mathrm{P}$ originating from seawater inflow or deepwater sediments. For STPs and freshwater sources, which are added directly to the upper $0-20 \mathrm{~m}$, the net of the term $P_{\text {Du }}$ is zero, but some mixing to the deep water may temporarily store small amounts of $\mathrm{P}$ in the deep water. The same loss fraction $f$ was applied for each source. It was determined for each day from the default model as the fraction of $\mathrm{P}$ loss from the surface water needed to balance the surface water $P$ budget. The loss fraction was set to zero for days with positive $\mathrm{P}$ balance for the upper 0-20 m, i.e., when there was a need for an internal net $\mathrm{P}$ source rather than $\mathrm{P}$ loss in this layer, e.g., by larger sediment $P$ release from shallow sediments than rate of $\mathrm{P}$ uptake or sedimentation. Thus, the summed concentrations from the model runs with single $\mathrm{P}$ sources were periodically lower than the observed $\mathrm{P}$ concentration, mainly in autumn and winter. Below, the additional net "unexplained" $\mathrm{P}$ input needed to balance the $\mathrm{P}$ budget for the $0-20$ - $\mathrm{m}$ layer is shown separately.

\section{Results}

\section{P Loads}

In the early 1970s, STPs totally dominated the external P load to the IA (Fig. 3, Walve et al. 2018). This load was drastically reduced, from nearly 900 tons year $^{-1}$ in 1970 , to less than 100 tons in 1976, decreasing further to $\sim 70$ tons year ${ }^{-1}$ in the 1980 s, $\sim 50$ tons year ${ }^{-1}$ in the first half of the 1990 s, and $~$ 30 tons year $^{-1}$ from 1996, when also $\mathrm{N}$ removal was implemented. In the period 1996-2015, the external P load was dominated by freshwater $\left(\sim 150\right.$ tons year $\left.{ }^{-1}\right)$ and seawater $(\sim$
102 tons year ${ }^{-1}$ ), with STPs contributing only $\sim 11 \%$ of the total load.

In 1970-1971, the start of P precipitation in STPs discharging to Lake Mälaren gave a notable reduction of the freshwater P load (Fig. 3b). TP in freshwater decreased from > 70 to $\sim 40 \mu \mathrm{g} 1^{-1}$ as yearly volume-weighted mean, decreased further in the 1980s and reached $\sim 27 \mu \mathrm{g} \mathrm{l}^{-1}$ from the 1990s onwards (Fig. 3c). After the drastic P load reduction in the 1970 s, most of the variability in the total external P loading has been due to variations in freshwater flow and hence freshwater P load (Fig. 3a, b). A combination of high freshwater flow and P concentration $\left(\sim 40 \mu \mathrm{g} \mathrm{l}^{-1}\right)$ in 1977-1988 resulted in high freshwater P loads (up to 300 tons year ${ }^{-1}$ ). This was followed in 1989-1997 by a period of lower flow and P concentration and reduced loads ( $75-150$ tons year ${ }^{-1}$ ). In 1998 2002, high freshwater flows again increased P loading, despite only small P concentration increases. From 2003 and onwards, freshwater $\mathrm{P}$ load and concentration returned to the lower levels of 1989-1997 (Fig. 3b, c). We found a trend of increasing seawater inflow volumes over the studied time period, but since the seawater $\mathrm{P}$ concentration has decreased slightly, the seawater TP load has remained relatively constant (Fig. 3). Over half of the annual sea and freshwater TP inputs was in the form of DIP (66 and 51\%, respectively, for 19962015 [2011 excl.]). Except for a higher DIP proportion in seawater inflow in the early 1970 s (80\%), there were no trends over the studied period in the proportion of DIP in sea and freshwater inflow (data not shown). DIP loads from STPs, available from 1989 onwards (Online resource 1), were relatively high in 1989-1990 $\left(\sim 21\right.$ tons year $\left.^{-1}\right)$, but then decreased to a rather constant level $\left(\sim 14\right.$ tons year $\left.{ }^{-1}\right)$. Thus, the share of DIP in the STP discharge increased from 20 $30 \%$ to $\sim 50 \%$ with lowered TP load from 50 to 30 tons year $^{-1}$.

\section{Source Partitioning of Surface Concentrations of TP and DIP}

To calculate the contribution of different $\mathrm{P}$ sources to the observed TP and DIP concentrations in the IA, the model was run with single $P$ sources as input, but with normal water balance. As expected, STPs explain the high P concentration in the early 1970s (Fig. 4). In the late 1970s and early 1980s, STPs, seawater, and freshwater contributed about equally to the observed TP concentration (Figs. 4 and 5). The P decrease from $\sim 50 \mu \mathrm{g} \mathrm{l}^{-1}$ in the early $1980 \mathrm{~s}$ to $25-30 \mu \mathrm{g} \mathrm{l} \mathrm{l}^{-1}$ from the mid-1990s is explained by decreased P contribution from both STPs and freshwater, while the contributions from seawater $(\sim$ $\left.11 \mu \mathrm{gl}^{-1}\right)$ and from deep-water sediment $\mathrm{P}$ release $\left(\sim 8 \mu \mathrm{g}^{-1}\right)$ showed no clear trends in this period (Fig. 5). The $\mathrm{P}$ contribution from freshwater decreased from $\sim 14$ to $\sim 7 \mu \mathrm{g} \mathrm{l^{-1 }}$ in 1985-1989 (Fig. 5). From the late 1980s to the late 1990s, the contribution from STPs also decreased by nearly $7 \mu \mathrm{g} 1^{-1}$, 
Fig. 3 Annual water flows (a), total P (TP) loads (b), and volume-weighted TP concentrations (c) of freshwater (FW), sewage treatment plant discharges (STPs), and modeled seawater inflow (SW). Note scale breaks in (b) and (c) and different scale for STPs in (a) and (c)
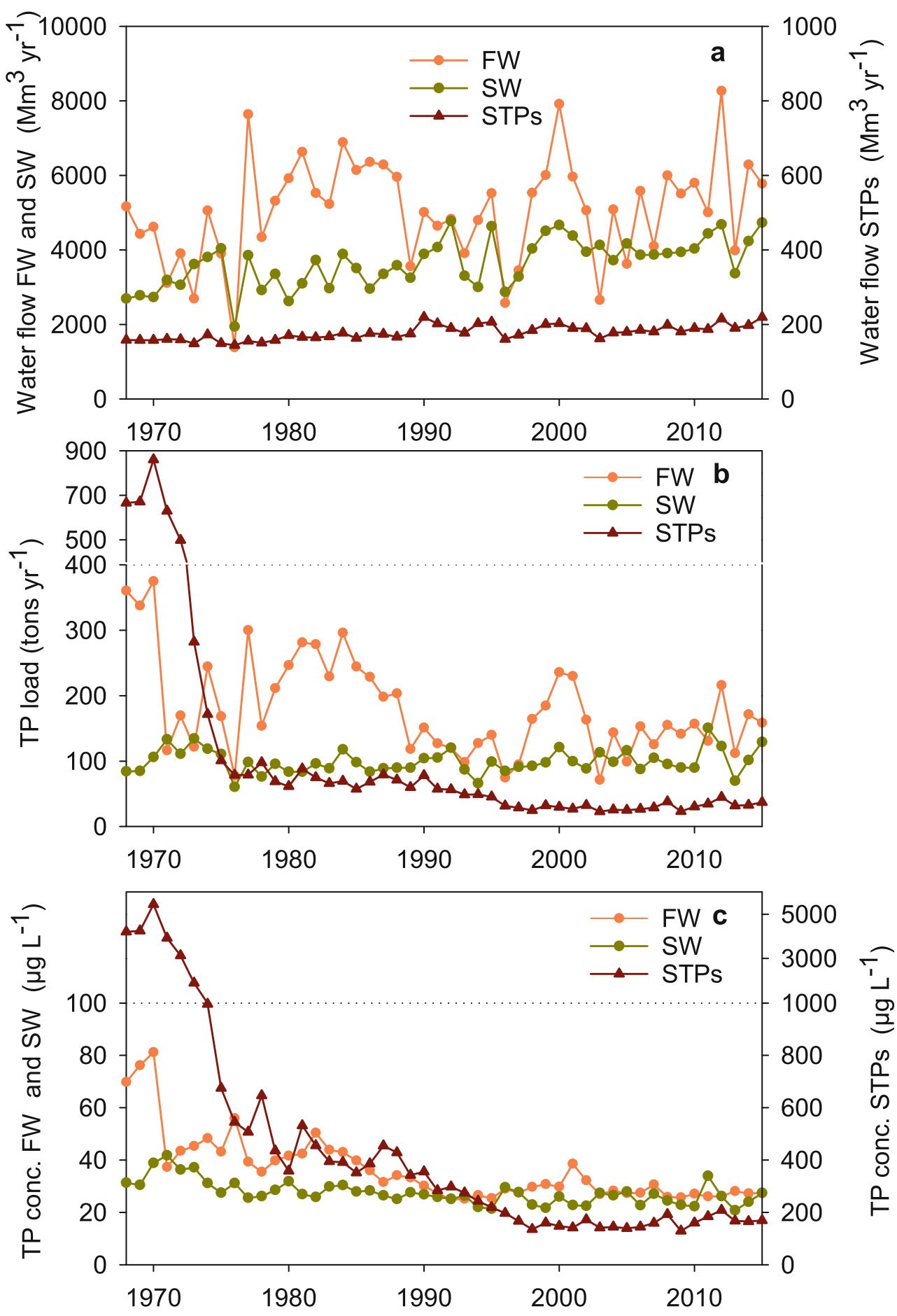

from $\sim 10(25 \%)$ to $3-4 \mu \mathrm{gl}^{-1}$ (12\%) (Fig. 5). For the period 1996-2015, the contributions to the annual mean TP in the 0 20 -m layer were dominated by seawater $(37 \%)$, followed by deep-water sediments (26\%), freshwater (25\%), and STPs (12\%) (Table 1).

The sum of the modeled separate contributions was sometimes lower than the TP concentration observed in the surface layer (0-20 m) (Fig. 4). This was not seen in spring but was most common in autumn, indicating P leakage from sediments shallower than $20 \mathrm{~m}$. This unexplained source, needed to balance the surface water budget, contributed up to $5 \mu \mathrm{g} \mathrm{l}^{-1}$ to the annual mean TP in the 1970s to early 1980s but became negligible from 1996 onwards (Fig. 5).

After the major drop in DIP concentration in 1971-1976, annual mean DIP was nearly constant until 1984, then declined until 1996, and then remained fairly constant at the 


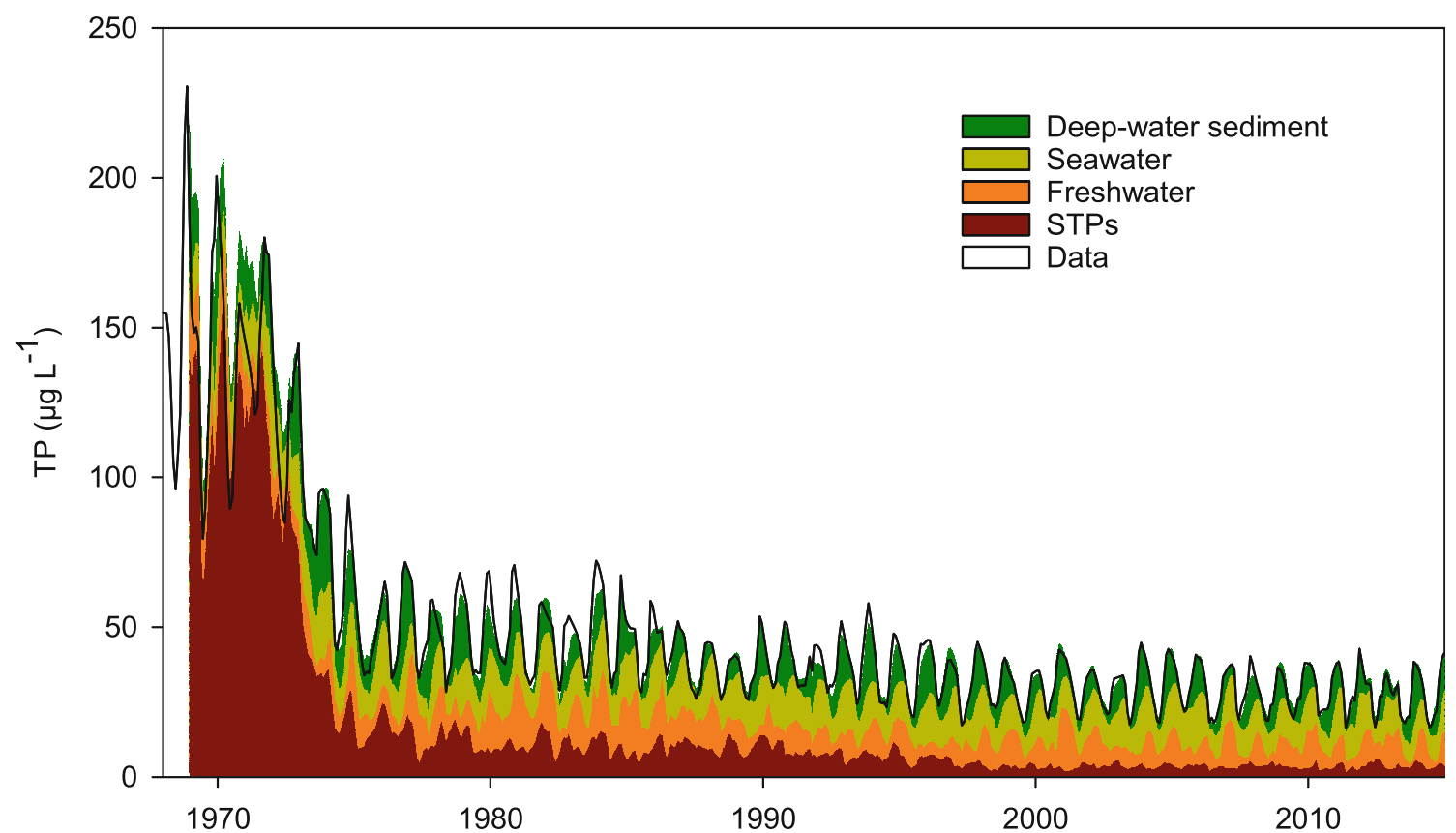

Fig. 4 Monthly means of modeled contributions of different $\mathrm{P}$ sources to total P (TP) concentration in the 0-20-m layer, estimated from separate model runs for each P source: deep water sediments ( $>20$ m water depth),

new, lower level (Online resource 1). Much of the decrease in DIP concentration from the mid-1980s was due to declining freshwater and seawater contributions. The influence of STPs and the unexplained source in surface water cannot be resolved before 1989 (missing STP data) but contribute little thereafter.

To evaluate the effect of variable freshwater and seawater flows on the contribution from STPs and deep-water sediments to $\mathrm{P}$ concentrations in the $0-20-\mathrm{m}$ layer, we ran the seawater, freshwater, and sewage treatment plants (STPs). Also shown are the depth- and volume-weighted monthly TP measurements (data)

model with these sources using daily flows each year according to a "mean year," based on daily means for the period 1968-2015. Compared with this mean year, low real flows gave low dilution of inputs from STPs and deep-water sediments and resulted in high concentrations, as was most evident in several dry years in the 1970s (Fig. 6) but was also seen in 1989, 1996, and 2003. Low concentrations due to high flows diluting inputs from STPs and deep-water sediments were most evident in 2000, 2001, and 2012.

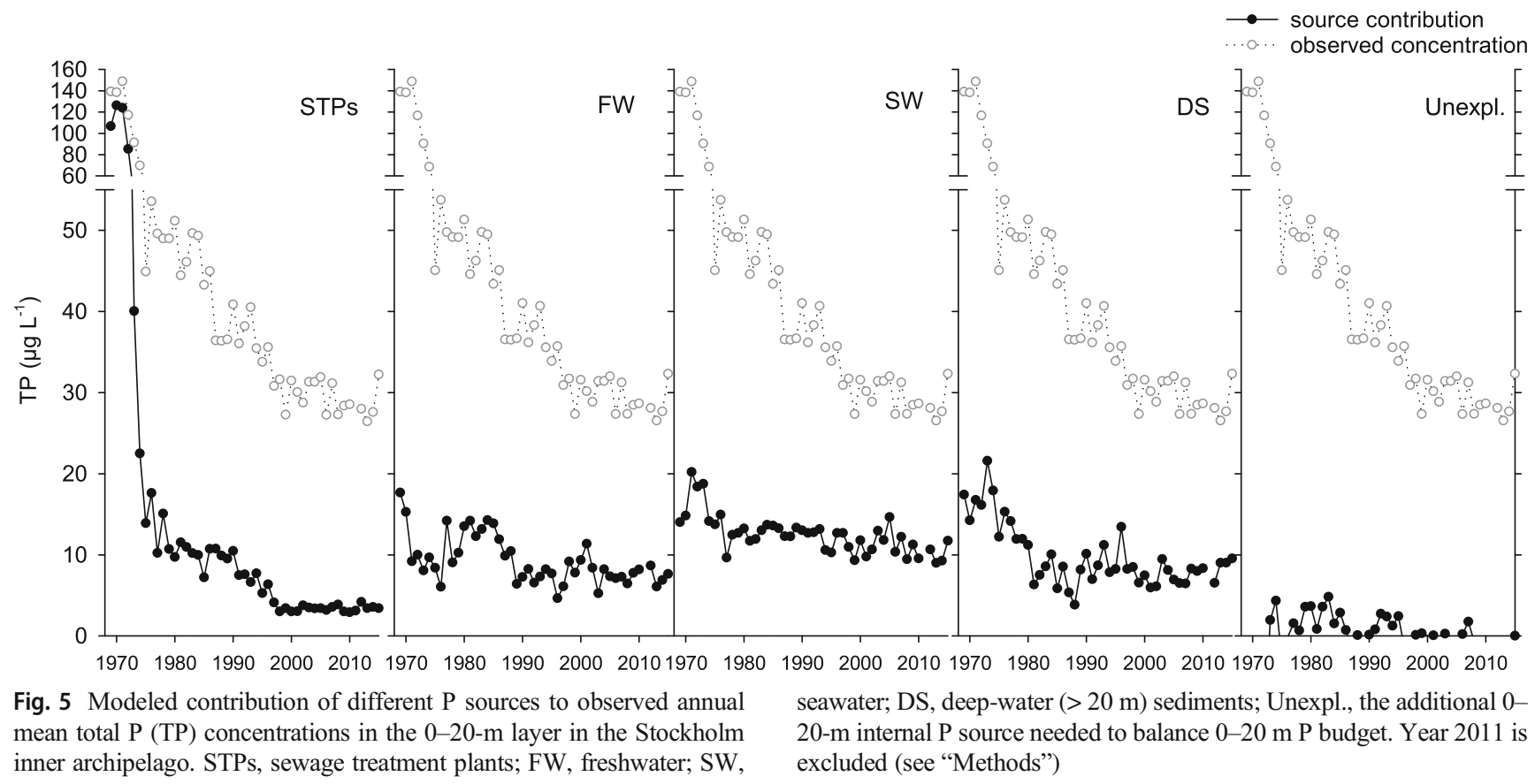




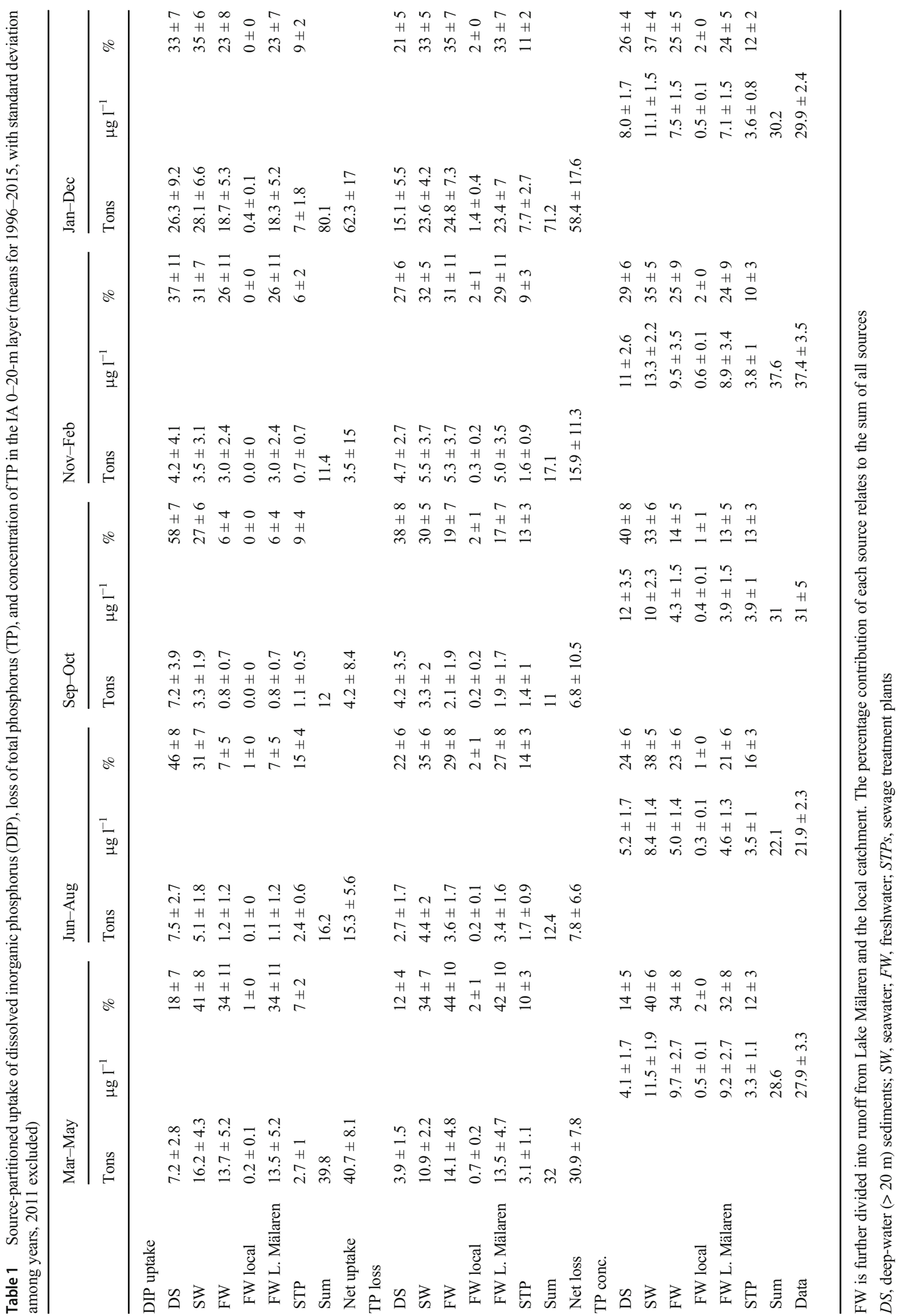


Fig. 6 Source contribution of sewage treatment plants (STPs) and deep-water sediments (DS, > $20 \mathrm{~m}$ ) to TP concentration $0-20$ $\mathrm{m}$, with real flow and long-term mean freshwater (FW) and seawater (SW) flows. Note that the highest TP concentrations in the 1970s are off the scale in the STP panel

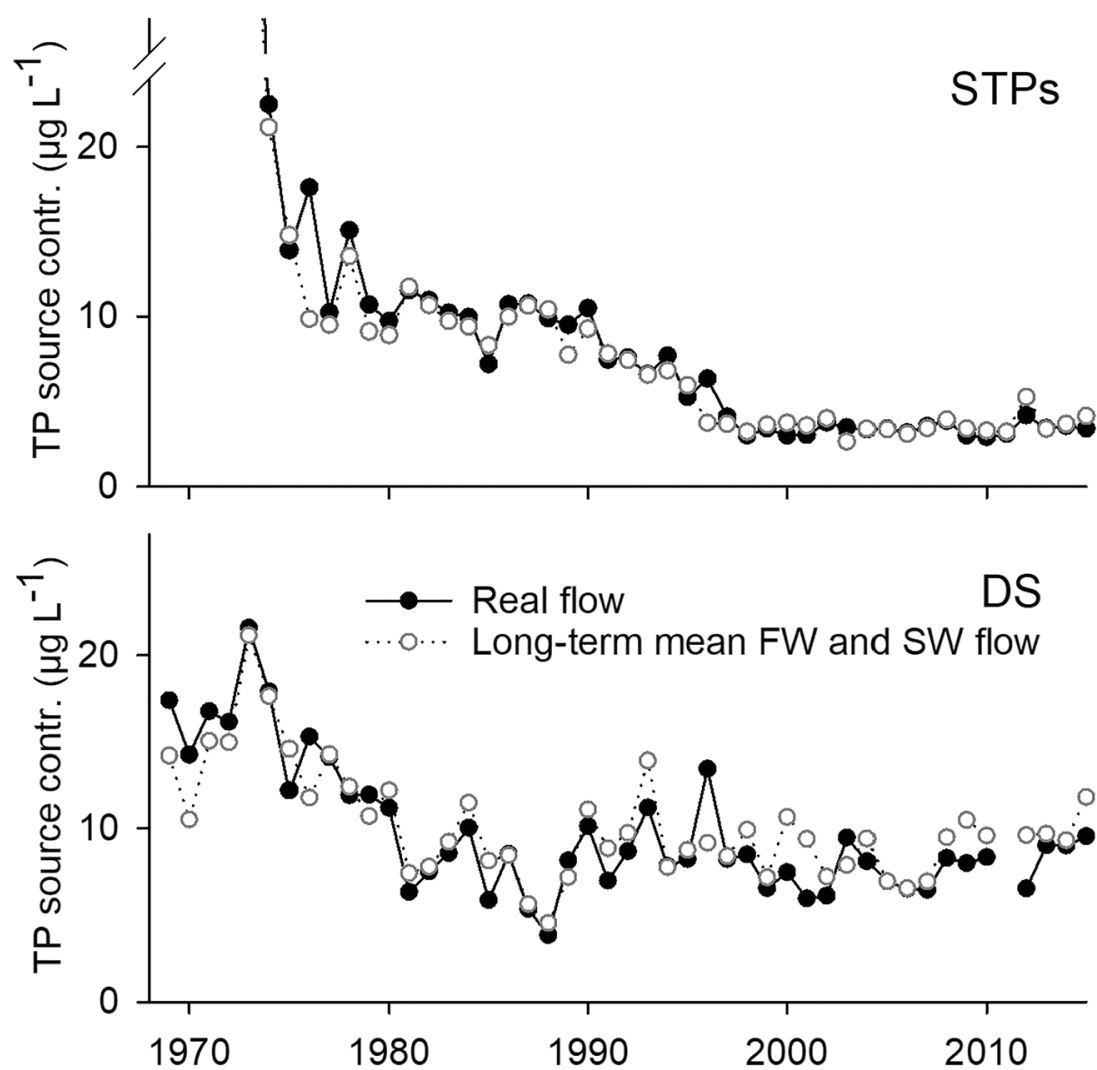

\section{Contribution of Different P Sources to Seasonal P Cycling}

The monthly mean $\mathrm{P}$ concentrations, external inputs, export and internal net loss rates of different $P$ sources in the $0-20-m$ layer were computed for the period 1996-2015 (Fig. 7; Table 1). At the end of February, before the start of the spring bloom, the DIP pool in the surface layer was $\sim 33$ tons $(25 \mu \mathrm{g}$ $\left.1^{-1}\right)$, with largest contribution from seawater (41\%), freshwater $(31 \%)$, and deep-water sediments $(23 \%)$ and only $6 \%$ from STPs (Fig. 7; Table 1). The DIP from deep-water sediments is mainly DIP remaining from sediment $P$ release in the preceding late summer and autumn that has been mixed up into the surface water in winter. Most of the DIP uptake occurred in the spring (March to May), with a peak in April (Fig. 7). By the end of May, only a few tons of DIP remained in the 0-20$\mathrm{m}$ layer. During spring, 51 tons of DIP was added to the surface layer (from seawater $35 \%$, freshwater $44 \%$, deepwater sediments $14 \%$, and STPs $7 \%$ ), and 37 tons was exported (Fig. 7). The DIP uptake in spring was $\sim 40$ tons, with seawater $(41 \%)$, freshwater $(34 \%)$, and deep-water sediments $(18 \%)$ as the main sources and STPs a minor source (7\%) (Table 1). The TP budget shows a spring TP loss from the $0-20-\mathrm{m}$ layer of 32 tons, indicating considerable loss through sedimentation (Fig. 7; Table 1).

In the summer months, June to August, a total DIP input of 26 tons to the surface layer was dominated by upwelling of P- rich deep water, which added $\mathrm{P}$ from deep-water sediments $(55 \%)$ and seawater (25\%). Freshwater (6\%) and STPs $(13 \%)$ were minor sources. This supported an estimated 16 tons of DIP uptake, plus some DIP export and some accumulation in the water mass $0-20 \mathrm{~m}$ (mainly in the 10-20-m layer). The source-partitioned DIP uptake in summer was dominated by deep-water sediments $(46 \%)$ and seawater (31\%), with freshwater $(7 \%)$ and STPs (15\%) as minor sources (Fig. 7).

In September and October, a total of $\sim 36$ tons of DIP reached the 0-20-m layer, mostly with P-rich deep water (deep-water sediments $54 \%$, seawater $27 \%$, freshwater $12 \%$, and STPs $7 \%$ of P input). In these months, much DIP accumulated in the water $(\sim 21$ tons $)$, with only partial uptake $(\sim 13$ tons) or export ( $\sim 9$ tons), summing to 43 tons. Missing DIP ( 7 tons) in this budget indicate periods with positive net internal DIP fluxes in the 0-20-m layer, with lower settling than sediment $\mathrm{P}$ release in this water layer. However, this varied among years.

\section{Discussion}

\section{Contributions of $\mathrm{P}$ Loads to Observed $\mathrm{P}$ Concentration}

Our results show that the improved P removal in STPs in the 1990s can largely explain the lower P concentration and thus potentially also some of the decrease in chlorophyll $a$ in the P- 


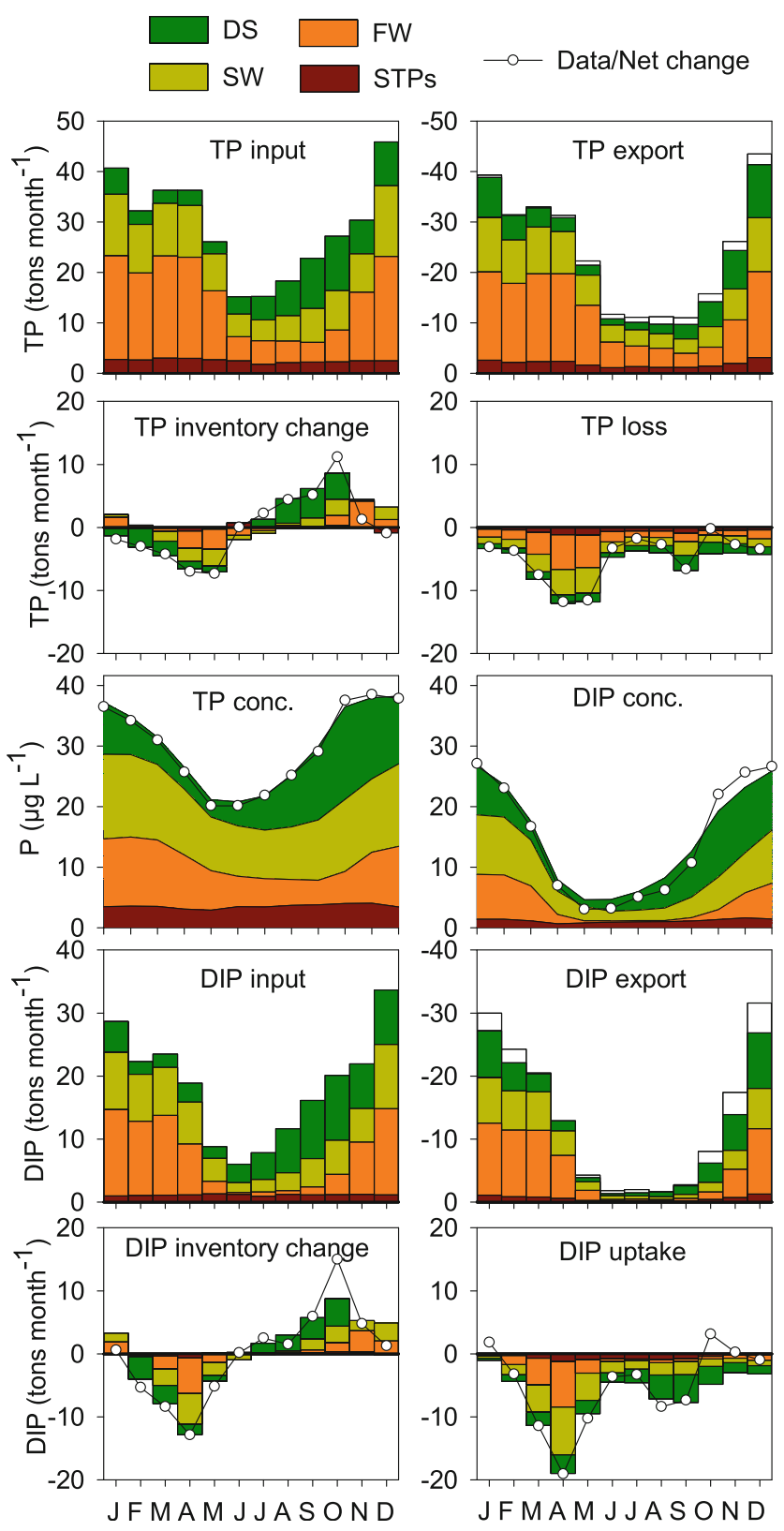

Fig. 7 Estimated monthly contribution of different TP and DIP sources to input, export, concentrations (end of month), change in water mass $\mathrm{P}$ inventory, and loss/uptake from the 0-20-m layer as means for 19962015, January to December. DS, deep-water sediments; SW, seawater; FW, freshwater; STPs, sewage treatment plants

limited IA. The potential for further water quality improvements due to higher P removal in the STPs is small. Even in summer, the season when the influence of STPs is maximal due to low freshwater flows, their contribution to $\mathrm{P}$ concentrations and DIP uptake is presently only $\sim 15-16 \%$ (means for 1996-2015, Table 1).

Declining freshwater $\mathrm{P}$ concentrations explain the $\mathrm{P}$ concentration decrease in the IA in the 1980s, but variations in flushing of the IA, primarily due to the freshwater flow, caused most of the variation in $\mathrm{P}$ concentrations. When flushing rate was high, point source inputs were diluted and the export increased, while at slow flushing, these $\mathrm{P}$ inputs tended to accumulate in the IA. The large increase in freshwater P loads in 1998-2001 was caused mainly by increased flow and only to a lesser extent by higher freshwater P concentration. Although the contribution of freshwater to the IA P concentration did increase, the elevated flushing rates counteracted buildup of P from STPs and deep-water sediments in the IA. Low flushing, promoting such buildup, can explain the apparent lack of effect in 1996 of the lowered STP P loads (Fig. 6).

While the P load from STPs and freshwater is well monitored, $\mathrm{P}$ in seawater inflow and seasonal $\mathrm{P}$ release from sediments have been largely unknown. In addition, not only freshwater but also seawater contributes to flushing of the IA. The DIP concentration in the Northern Baltic Proper was relatively low in the early 1970s but has since increased (FlemingLehtinen et al. 2008). In contrast, inflowing seawater to the IA had relatively high TP and DIP concentrations in the early 1970s when the P loading from STPs to the IA was very high (Fig. 3), indicating that $P$ exported from the IA was partly reimported with the seawater inflow. From the late 1970s onwards, P loading from land (freshwater+STPs) and the P concentration of seawater inflow were unrelated. The current annual seawater volume inflow and P load is of the same magnitude as the freshwater input, except in wet years, when the freshwater flow and P load is larger.

Internal P loading from historical sediment $\mathrm{P}$ deposits has been suggested to have counteracted the improvement of water quality of the IA, in terms of P concentration and chlorophyll (Schindler and Vallentyne 2008). However, net budgets for the IA indicate that discernable legacy $P$ loads were restricted to the first 10-20 years after the major load reduction in the 1970s and that most of the current $\mathrm{P}$ release from deep-water sediments (> $20 \mathrm{~m}$ ) is a seasonal P recycling (Walve et al. 2018). We estimate here the TP and DIP inputs from deep-water sediments that reach the upper $20 \mathrm{~m}$ as a result of upwelling, in turn driven by seawater inflow, and to a lesser extent, vertical mixing due to wind. This P source was relatively large in the 1970s (Fig. 6), partly due to legacy $\mathrm{P}$ release and partly due to large seasonal recycling (Walve et al. 2018), and in several years also reinforced by low flushing rates in this relatively dry period (Fig. 6). From 1980 and onwards, the influence of $P$ release from deepwater sediments varied greatly from year to year $\left(3-12 \mu \mathrm{g} \mathrm{l}^{-1}\right)$ but did not decline. This inter-annual variability was mainly related to differences in $\mathrm{P}$ recycling due not only to variable $\mathrm{P}$ settling and oxygen conditions (Walve et al. 2018) but also to variable surface water flushing rates (Fig. 6).

Although most $P$ settled in spring appears to be recycled in the deep water, release from shallow bottoms $(<20 \mathrm{~m})$ can potentially be large in years of shallow water hypoxia (Walve et al. 2018). In some years a seasonal net internal P source < $20 \mathrm{~m}$ was needed to explain the observed concentrations in late summer and autumn, suggesting that $\mathrm{P}$ release from 
shallow sediments was larger than P settling from the water column. Our data indicate that a decrease in such net $\mathrm{P}$ release contributed to the observed decline in surface $\mathrm{P}$ concentration after 1995 (Fig. 5). Stronger mixing after 1990 and lower STP BOD loads from 1996 (mainly less ammonium) have clearly increased oxygen availability in intermediate layers $(8-20 \mathrm{~m})$ of the IA (Lännergren and Stehn 2011; Walve et al. 2018) and may explain the decreasing P release from shallow bottoms.

An important assumption, needed to allow calculation of the contributions of different $\mathrm{P}$ sources to the TP concentration, was that each source contributes proportionally to $P$ sedimentation. However, while P release from sediments is mostly in the form of DIP (Walve et al. 2018), the other sources contain a relatively large share of particulate $\mathrm{P}$ and dissolved organic P (DOP) of variable bioavailability. The summer DIP concentration in Lake Mälaren is low and freshwater P inputs in summer are mainly as particulate $\mathrm{P}$ and DOP. This DOP is probably low on bioavailable $\mathrm{P}$ due to plankton $\mathrm{P}$ uptake in the P-limited Lake Mälaren and should largely be exported from the IA. DIP from deep-water sediments and seawater dominate DIP uptake in summer (Fig. 7) and should contribute more than freshwater to summer primary production and sedimentation. The contribution of freshwater to the TP concentration is therefore likely underestimated relative to other $\mathrm{P}$ sources in summer, although its direct impact on productivity is small. However, in winter and spring, freshwater is a clear DIP source, contributing to spring DIP uptake (see below) and $\mathrm{P}$ settling, which dominates the annual net $\mathrm{P}$ loss. The DIP uptake should be independent of DIP source and its partitioning therefore relatively robust. The bioavailability of particulate P originating from the STP load is uncertain, but before the improved N- and P-treatment in 1996, flocks of iron-bound $\mathrm{P}$ probably dissolved in the low-oxygen water current formed by the treated sewage water or when reaching deeper water or sediments low in oxygen. Although the improved P removal in STPs had limited effect on DIP loads, the input of flocks of iron-bound P may have been substantially reduced after 1995. However, it is unclear to what extent the changed particulate P load from STPs have affected the IA DIP pool and uptake. Since the surface water P budget gives net loss rather than gross $\mathrm{P}$ sedimentation rates and release from sediments in this layer, the contribution of recycled DIP from sediments to DIP uptake and to the P concentration is a minimum estimate. If gross $\mathrm{P}$ inputs from surface water sediments could be quantified and added as a $\mathrm{P}$ source, it would decrease the relative contribution of other sources to the TP concentration, mostly in summer, and their settling would be correspondingly higher.

\section{P Sources for Phytoplankton Production}

There is a large net loss of TP (Walve et al. 2018; Fig. 7) and DIP (Fig. 7) from the surface water in March to May, consistent with the timing of the phytoplankton spring bloom (Lännergren and Stehn 2011). Phytoplankton counts show that diatoms are an important component of these blooms, as is also evident from the decrease in dissolved silicate concentrations (Lännergren and Stehn 2011). A diatom-dominated spring bloom consuming most of the nutrients is typical of many temperate estuaries (e.g., Testa and Kemp 2008). Most of the bloom then sinks into deeper water or settles to the sediment (Blomqvist and Larsson 1994). Other processes likely contribute little to internal P loss. Due to the morphology and salinity of the IA, there are no mussel beds and limited benthic vegetation, and these have maximum growth in summer, not spring. Blomqvist and Larsson (1994) report settling rates of primary organic $\mathrm{C}$, measured with sediment traps in the southern Stockholm archipelago (Himmerfjärden), of $0.4 \mathrm{~g} \mathrm{C} \mathrm{m}^{-1}$ day $^{-1}$ in spring, or $\sim 8 \mathrm{mg} \mathrm{P} \mathrm{m}^{-2}$ day $^{-1}$. Our value in April and May for the IA (Fig. 7) is lower (12 tons P month $^{-1}$ or $4 \mathrm{mg} \mathrm{P} \mathrm{m}^{-2}$ day $^{-1}$ ). Besides the influence of different areas, years, and possible measurement errors, some of the difference may relate to the longer period included in our mean, as the spring sedimentation peak may be relatively short.

The spring bloom uses DIP accumulated in the surface water during winter as well as DIP added to the photic zone during the bloom. Our results show that the winter storage of nutrients in the IA water mass greatly underestimates the DIP available to the spring bloom. Source partitioning the spring bloom DIP uptake (for 1996-2015), shows it depends mainly on the seawater, freshwater, and sediment supply of DIP, while direct emissions from STPs add little $(\sim 7 \%)$. The big DIP release from sediments in summer and autumn is largely exported with outflowing surface water in autumn and winter, but some still remains in the IA to support the spring bloom ( $18 \%$ of total spring DIP uptake). Although hypoxia influences year-to-year variability of sediment $\mathrm{P}$ release, this is mainly governed by the amount of $\mathrm{P}$ deposited by the preceding spring bloom (Walve et al. 2018). Thus, the external seawater and freshwater $\mathrm{P}$ sources are ultimate drivers of the $\mathrm{P}$ cycle in the IA, contributing not only directly to spring bloom DIP supply but also indirectly supplying most of the $\mathrm{P}$ recycled from the sediment.

After addition of $\mathrm{N}$ reduction in STPs in 1996, summer DIN concentrations have fallen in the outer section of the IA and in the middle archipelago (Lännergren and Stehn 2011). Surface layer DIP concentrations have remained low through July and August, with continuous phytoplankton uptake of new DIP inputs, largely originating from deep-water sediments (Fig. 7). Our estimate of apparent (net) DIP uptake does not include the $P$ recycled within the surface layer. In addition to the recycling from shallow sediments, other internal sources, such as recycling from pelagic and benthic fauna and microbes, will add to the gross DIP uptake by primary producers, especially in summer. Such DIP turnover should be 
relatively rapid, compared with that of sediments, which have longer P recycling time lags, with seasonal and some betweenyear storage, but apparently little longer-term P storage (Walve et al. 2018).

\section{Effect of Seawater and Deep-Water Sediments on IA Management Targets}

The Swedish implementation of the WFD status classification uses defined reference $P$ concentrations of freshwater and seawater surface water endmembers and a simple mixing model to estimate the reference $\mathrm{P}$ concentrations at a specific salinity (Hansson and Håkansson 2006; HVMFS 2013, 2018; Viktorsson and Wesslander 2017). However, as our study shows, P settling and release from sediments redistributes nutrients from spring to summer and even to the following winter, meaning that simple mixing models can underestimate reference values for the present seasonal assessment periods (July-August and December-February).

In winter, observed IA winter TP and DIP concentrations are 14 and $20 \%$ higher than expected from simple mixing of observed (1996-2015) winter seawater and freshwater endmembers of TP and DIP (Online resource 1). This implies that IA reference values based on simple mixing are correspondingly underestimated for winter, due to remaining $\mathrm{P}$ recycled from sediments. In summer, $\mathrm{P}$ concentrations are more influenced by the net settling loss of $\mathrm{P}$ in spring, and mixing of $P$ from deep-water sediments to surface waters is delayed. Even if much of the surface water $P$ in summer originates from sediment $\mathrm{P}$, simple mixing of observed (19962015) summer freshwater and seawater endmembers results in values not far from the observed IA concentration. This implies that for summer, settling compensates for inputs from sediment $\mathrm{P}$ release, and a simple mixing model is relatively correct.

Seawater inflow directly influences $P$ concentrations in the IA surface water through upwelling of deep water containing seawater P. In the Swedish WFD assessment, the reference seawater endmember is open Baltic Sea surface water (HVMFS 2018). This is unrealistic for the Stockholm IA, since seawater inflow to the IA originates from middle archipelago deep water that during its inward transport through archipelago has received additional $\mathrm{P}$ from sediments, as indicated by high seawater $\mathrm{P}$ concentration in October to November. Thus, also the reference seawater endmember may need correction for sediment $\mathrm{P}$ inputs, when applied to the Stockholm IA. The observed seawater endmember (Trälhavet deep water, 1996-2015) has 22\% higher winter TP concentration (31\% higher winter DIP, $45 \%$ higher summer TP) than surface water of the open sea (Online resource 1). If this difference applies to reference conditions, resulting IA reference values should be $7 \%$ (winter TP), $14 \%$ (winter DIP), and $16 \%$ (summer TP) higher than present values. If corrected also for IA sediment influence, IA reference winter TP should be $22 \%$, and winter DIP 36\%, higher than present reference values. The same corrections will apply to the goodmoderate boundary. However, even the corrected seawater endmembers are lower than the observed seawater concentrations, which would need to be reduced by ca. $20-30 \%$ for winter TP and DIP and $10 \%$ for summer TP to reach the good-moderate boundary. Our model shows that such reductions cannot be achieved through local remediation measures only, but require successful management on the Baltic Sea scale.

\section{Effects of Further P or N Load Reductions}

The significantly improved water quality in the IA as a result of reduced P inputs (Brattberg 1986; Boesch et al. 2006; Walve et al. 2018) has sometimes been taken as confirmation that $\mathrm{P}$ reductions alone (without $\mathrm{N}$ reductions) are enough to counteract the eutrophication of estuaries and coastal zones in general (Schindler et al. 2008; Schindler 2012), in contrast with the general view (Howarth and Marino 2006; Paerl 2009). Our study not only shows a clear direct effect of the reduced P loads from STPs in 1996 on the IA TP concentrations but also indicates that the lowered load of oxygenconsuming ammonium has decreased the $\mathrm{P}$ release from shallow sediments. In addition, $\mathrm{N}$ data (Lännergren and Stehn 2011) show that the $\mathrm{N}$ removal has moved the transition zone between $\mathrm{N}$ and $\mathrm{P}$ limitation inwards, closer to the outer border of the IA. Further reduced $\mathrm{N}$ inputs would not only reduce eutrophication of the middle and outer archipelago but could also make the outer parts of the IA N-limited. This could potentially increase the occurrence of $\mathrm{N}$-fixing cyanobacteria in summer in this zone. However, this should be counteracted by lower settling of $\mathrm{P}$ and organic matter in $\mathrm{N}$-limited parts of the IA resulting in larger $\mathrm{P}$ export and lower internal $\mathrm{P}$ recycling from sediments. Clearly, cyanobacteria could not become as abundant as in the early 1970s, when both Nfixing and non-N-fixing cyanobacteria thrived in the highly $\mathrm{N}$ - and P-enriched conditions (Brattberg 1986).

\section{Conclusions}

Our study demonstrates the value of a relatively simple waterexchange box model for evaluating the contribution of different $P$ sources that fertilize the surface water with DIP, potentially available for primary production. Introduction of $\mathrm{P}$ precipitation in STPs in the 1970s drastically reduced P concentrations in the Stockholm IA surface water. Subsequently, further improved P removal in STPs and lowered freshwater $\mathrm{P}$ loads explain most of the continued decline of $\mathrm{P}$ concentrations in the IA, but indirect effects on $\mathrm{P}$ cycling of the $\mathrm{N}$ reduction introduced from 1996 may also have contributed. 
In wet years, large flows of seawater and freshwater dilute inputs from point sources and sediments, lowering $\mathrm{P}$ concentrations. In dry years, $\mathrm{P}$ tends to accumulate in the IA. This increases the variability in the $\mathrm{P}$ time-series, and affects its interpretation in relation to loads. Evaluations of the effect of $\mathrm{P}$ on water quality cannot only be done based on $\mathrm{P}$ loads alone but has also to consider water flows. For example, periods of one or several dry years can explain why lowered $\mathrm{P}$ loads from point sources do not improve water quality as expected. Counterintuitively, large loads can decrease, rather than increase, $\mathrm{P}$ concentrations in the estuary, if the large load is due to high freshwater flow.

At present, seawater and freshwater are the main drivers of the IA P cycle, by fertilizing the spring bloom, leading to the subsequent summer sediment DIP release. This release is largely exported with outflowing surface water in autumn and winter. Some remains in the IA to support the next spring bloom, but the year-to-year memory effect is weak. The response to changed nutrient loading from external sources is therefore relatively rapid in the IA, compared with archipelago bays with more restricted water exchange, where internal year-to-year recycling is more important (e.g., Rydin et al. 2017).

When setting $\mathrm{P}$ management targets, the contribution of seasonal sediment $\mathrm{P}$ release to surface water $\mathrm{P}$ concentrations should be taken into account in this, and probably many other, Baltic coastal waters. In the stratified Stockholm IA this is most obvious for winter P concentrations, as P-rich deep water is successively mixed into surface waters. The large P import with seawater, which in practice makes good status unattainable through local measures, highlights the need for reducing $\mathrm{P}$ concentrations in the open Baltic Sea. Further lowered N loads to the IA could also contribute to improved IA water quality if its outer parts become N-limited. In addition to the direct effect on productivity in these areas, N-limitation may decrease $\mathrm{P}$ uptake and recycling to P-limited parts of the IA.

Acknowledgments Data were kindly provided by Stockholm Vatten AB (now Stockholm Vatten och Avfall).

Funding Information Open access funding provided by Stockholm University. Model development was initiated in EU project SPICOSA and was also financially supported by Sydvästra Stockholmsregionens va-verksaktiebolag (SYVAB). Data compilation and model analysis were supported by grants from Svealands kustvattenvårdsförbund (SKVVF). The Swedish EPA and Stockholm Vatten AB contributed funding for digitizing old data.

Open Access This article is licensed under a Creative Commons Attribution 4.0 International License, which permits use, sharing, adaptation, distribution and reproduction in any medium or format, as long as you give appropriate credit to the original author(s) and the source, provide a link to the Creative Commons licence, and indicate if changes were made. The images or other third party material in this article are included in the article's Creative Commons licence, unless indicated otherwise in a credit line to the material. If material is not included in the article's Creative Commons licence and your intended use is not permitted by statutory regulation or exceeds the permitted use, you will need to obtain permission directly from the copyright holder. To view a copy of this licence, visit http://creativecommons.org/licenses/by/4.0/.

\section{References}

Blomqvist, S., and U. Larsson. 1994. Detrital bedrock elements as tracers of settling resuspended particulate matter in a coastal area of the Baltic Sea. Limnology and Oceanography 39 (4): 880-896.

Blomqvist, S., A. Gunnars, and R. Elmgren. 2004. Why the limiting nutrient differs between temperate coastal seas and freshwater lakes: A matter of salt. Limnology and Oceanography 49 (6): 2236-2241.

Boesch, D., R. Hecky, C. O’Melia, D. Schindler, and S. Seitzinger. 2006. Eutrophication of Swedish seas. Swedish Environmental Protection Agency Report 5509. www.naturvardsverket.se.

Brattberg, G. 1986. Decreased phosphorus loading changes phytoplankton composition and biomass in the Stockholm archipelago. Vatten 42: 141-152.

Brattberg, G., L.G. Reinius, and M. Tendaj. 1991. Optimization of nutrient removal in Stockholm. Water Science and Technology 24 (7): $103-111$.

Breitburg, D., L.A. Levin, A. Oschlies, M. Gregoire, F.P. Chavez, D.J. Conley, V. Garcon, D. Gilbert, D. Gutierrez, K. Isensee, G.S. Jacinto, K.E. Limburg, I. Montes, S.W.A. Naqvi, G.C. Pitcher, N.N. Rabalais, M.R. Roman, K.A. Rose, B.A. Seibel, M. Telszewski, M. Yasuhara, and J. Zhang. 2018. Declining oxygen in the global ocean and coastal waters. Science 359: 46.

Cloern, J.E. 2001. Our evolving conceptual model of the coastal eutrophication problem. Marine Ecology-Progress Series 210: 223-253.

Dettmann, E.H. 2001. Effect of water residence time on annual export and denitrification of nitrogen in estuaries: A model analysis. Estuaries 24 (4): 481-490.

Engqvist, A., and O. Andrejev. 2003. Water exchange of the Stockholm archipelago - a cascade framework modelling approach. Journal of Sea Research 49 (4): 275-294.

Fleming-Lehtinen, V., M. Laamanen, H. Kuosa, H. Haahti, and R. Olsonen. 2008. Long-term development of inorganic nutrients and chlorophyll alpha in the open northern Baltic sea. Ambio 37 (2): 86 92.

Hansson, M., and B. Håkansson. 2006. Förslag till Vattendirektivets bedömningsgrunder för pelagiala vintertida näringsämnen och sommartida effektrelaterade näringsämnen i kust- och övergångsvatten. SMHI report, Dnr: 2005/1278/1933.

Hedenstierna, B. 1948. Stockholms skärgård. Kulturgeografiska Undersökningar i Värmdö Gamla Skeppslag. Geografiska Annaler 30: 1-444 (in Swedish).

Howarth, R.W., and R. Marino. 2006. Nitrogen as the limiting nutrient for eutrophication in coastal marine ecosystems: Evolving views over three decades. Limnology and Oceanography 51: 364-376.

HVMFS. 2013. Havs- och vattenmyndighetens föreskrifter om klassificering och miljökvalitetsnormer avseende ytvatten. Havsoch vattenmyndighetens författningssamling 2013: 19 (in Swedish).

HVMFS. 2018. Havs- och vattenmyndighetens föreskrifter om ändring $\mathrm{i}$ Havs- och vattenmyndighetens föreskrifter (HVMFS 2013:19) om klassificering och miljökvalitetsnormer avseende ytvatten. Havsoch vattenmyndighetens författningssamling 2018: 17 (in Swedish).

Lännergren, C., and A. Stehn. 2011. Undersökningar i Stockholms skärgård 2010. Stockholm Vatten report 2011-04-11, Dnr 10SV299 (in Swedish).

Nixon, S.W., J.W. Ammerman, L.P. Atkinson, V.M. Berounsky, G. Billen, W.C. Boicourt, W.R. Boynton, T.M. Church, D.M. Ditoro, R. Elmgren, J.H. Garber, A.E. Giblin, R.A. Jahnke, N.J.P. Owens, 
M.E.Q. Pilson, and S.P. Seitzinger. 1996. The fate of nitrogen and phosphorus at the land sea margin of the North Atlantic Ocean. Biogeochemistry 35 (1): 141-180.

Paerl, H.W. 2009. Controlling eutrophication along the freshwatermarine continuum: dual nutrient $(\mathrm{N}$ and $\mathrm{P})$ reductions are essential. Estuaries and Coasts 32 (4): 593-601.

Rydin, E., L. Kumblad, F. Wulff, and P. Larsson. 2017. Remediation of a eutrophic bay in the Baltic Sea. Environmental Science and Technology 51 (8): 4559-4566.

Scavia, D., and Y. Liu. 2009. Exploring Estuarine Nutrient Susceptibility. Environmental Science, and Technology 43 (10): 3474-3479.

Schindler, D.W. 2012. The dilemma of controlling cultural eutrophication of lakes. Proceedings of the Royal Society B-Biological Sciences 279 (1746): 4322-4333.

Schindler, D.W., and J.R. Vallentyne. 2008. The algal bowl. Overfertilization of the world's freshwaters and estuaries. London: Earthscan.

Schindler, D.W., R.E. Hecky, D.L. Findlay, M.P. Stainton, B.R. Parker, M.J. Paterson, K.G. Beaty, M. Lyng, and S.E.M. Kasian. 2008. Eutrophication of lakes cannot be controlled by reducing nitrogen input: Results of a 37-year whole-ecosystem experiment. Proceedings of the National Academy of Sciences of the United States of America 105 (32): 11254-11258.

SMHI. 2003. Djupdata för havsområden. SMHI Oceanography Report, No 73, Swedish Meteorological and Hydrographical Institute, ISSN 0283-7714, Norrköping, 69 p (in Swedish).

Staehr, P.A., J. Testa, and J. Carstensen. 2017. Decadal changes in water quality and net productivity of a shallow Danish Estuary following significant nutrient reductions. Estuaries and Coasts 40 (1): 63-79.
Testa, J.M., and W.M. Kemp. 2008. Variability of biogeochemical processes and physical transport in a partially stratified estuary: a boxmodeling analysis. Marine Ecology Progress Series 356: 63-79.

Testa, J.M., W.M. Kemp, L.A. Harris, R.J. Woodland, and W.R. Boynton. 2017. Challenges and directions for the advancement of estuarine ecosystem science. Ecosystems 20 (1): 14-22.

Viktorsson, L., and K. Wesslander. 2017. Revidering av fysikaliska och kemiska bedömningsgrunder i kustvatten. Underlag inför uppdatering av HVMFS 2013:19. SMHI report.

Walve, J. 2012. Värdefull tidsserie riskerar att förstöras. Svealandskusten 2012, Svealands Kustvattenvårdsförbund, Stockholm, Sweden, 14 15 (in Swedish).

Walve, J., M. Sandberg, U. Larsson, and C. Lännergren. 2018. A Baltic Sea estuary as a phosphorus source and sink after drastic load reduction: seasonal and long-term mass balances for the Stockholm inner archipelago for 1968-2015. Biogeosciences 15 (9): 3003 3025 .

WFD. 2000. Directive 2000/60/EC of the European Parliament and of the Council of 23 October 2000 establishing a framework for Community action in the field of water policy. Official Journal of the European Communities L327: 1-72.

Zhang, J., D. Gilbert, A.J. Gooday, L. Levin, S.W.A. Naqvi, J.J. Middelburg, M. Scranton, W. Ekau, A. Pena, B. Dewitte, T. Oguz, P.M.S. Monteiro, E. Urban, N.N. Rabalais, V. Ittekkot, W.M. Kemp, O. Ulloa, R. Elmgren, E. Escobar-Briones, and A.K. Van der Plas. 2010. Natural and human-induced hypoxia and consequences for coastal areas: synthesis and future development. Biogeosciences 7 (5): 1443-1467. 